\title{
Метафоричні моделі особистої власності в економічній свідомості підлітків
}

Анотація. Стаття присвячена актуальній проблемі концептуалізації реальності відносин особистої власності учнями підліткового віку. Показані результати контент-аналізу метафоричного змісту економічних казок підлітків. Відповідно описуються особливості розуміння й оиінки підлітками реальності відносин особистої власності. Зокрема, аналізуються метафоричні моделі особистих благ людини, що веде своє господарство. Ці моделі показані як характеристики когнітивних, а не лінгвістичних засобів, за допомогою яких дійсність особистої власності підлітками осмислюється, категоризується і конщептуалізується. Показані особливості осмислення підлітками ролі власника в особистій економіиі.

Ключові слова: підлітки, економічна свідомість, економічна культура особистості, особиста власність, метафорична модель.

Постановка проблеми. Труднощі, яких зазнає сьогодні українська економіка, на наш погляд, можуть виявитись нездоланними поза цілеспрямованою економічною соціалізацією молоді, зокрема, учнівської, як суб’єктів успішної господарської діяльності. При цьому йдеться про соціалізованість молодих українців як такий рівень сформованості економічної культури, який забезпечив би здатність успішно діяти в умовах ринкової економіки, орієнтованої на цінності вільної конкуренції, відкритості, свободи і відмови від монополізму в усіх сферах економічної діяльності тощо. У цьому контексті в науковому плані актуальною є проблема емпіричного вивчення наявного рівня економічної соціалізованості учнівської молоді, зокрема, на етапі дорослішання і початку самостійного практикування економічних відносин (купівліпродажу, найманої праці, інвестування, волонтерства тощо) у підлітковому віці.

Аналіз останніх досліджень. Поняття «економічної культури особистості» тільки віднедавна введене в тезаурус психологічної науки. При цьому економічна культура підлітків як соціально-психологічний феномен вивчалась досить фрагментарно, в окремих аспектах [2; 4]. Йшлося переважно про монетарну соціалізацію: вивчались особливості ставлення до кишенькових грошей та їх соціалізуюча роль.
Співробітниками лабораторії соціальної психології Інституту психології імені Г.С. Костюка НАПН України $[1 ; 2 ; 4 ; 6 ; 8]$ економічна культура вивчається як результат і показник економічної соціалізованості особистості. Однак зазначимо, що економічна культура особистості формується у більш широкому контексті — не тільки у монетарних відносинах, але й у просторі відносин, опосередкованих більшою кількістю економічних благ, матеріальних і духовних, - у просторі власності. Хоча юридично дитина не вважається самостійним суб'єктом власності, тим не менш $є$ така форма власності, в яку дитина включена чи не 3 народження. Йдеться про особисту власність, про ті відносини, в яких дитина соціалізується як суб'єкт привласнення особистих благ, усього того, що, відчуживши від когось іншого, вважає своїм і від володіння чи користування яким отримує своєрідний зиск, перш за все, духовний. Тому нами обгрунтовується ідея про те, що економічна культура підростаючої особистості має, перш за все, вивчатись у контексті їі включення у відносини особистої власності. Останні досліджуються як системотворчі для особистої економіки дитини. Увесь період економічної соціалізації особистості, починаючи з дитинства, вони чинять вирішальний вплив на конституювання економіко-психологічного простору 
особистості та становлення системи тих економіко-психологічних якостей, завдяки яким вона успішно реалізується як суб'єкт господарської діяльності [1]. У такому ракурсі соціально-психологічні детермінанти становлення економічної культури учнівської молоді, зокрема, підлітків, у вітчизняній економічній психології не вивчались.

Отже, оскільки особиста власність розглядається нами як системне явище, а не як сукупність окремих феноменів (власника, об'єкта привласнення, інших суб'єктів), то актуальним $є$ пошук тих методичних засобів, які б дозволили вивчити реальність особистої власності, якою вона $€$ в свідомості підлітків як системне явище. Одним $з$ таких інструментів обгрунтовуємо метафоричну модель особистої власності. У фокусі нашої уваги $є$ метафоричний зміст уявлень підлітків про особисте майно, про себе та інших як власників. Метафорична модель [7, с. 387] взята нами як один із засобів системної репрезентації результатів мовленнєвого конструювання картини світу особистої економіки підлітка. При цьому, слідом за авторами наукового видання «Спілкування та пізнання», будемо користуватись терміном «метафорична модель» [9, с. 374] для характеристики когнітивних, а не лінгвістичних, засобів (уявлень, репрезентацій, понять тощо), за допомогою яких дійсність особистої власності осмислюється, категоризується і концептуалізується підлітками.

Таким чином, метою даної статті $\epsilon$ висвітлення результатів емпіричного дослідження метафоричних моделей особистої власності в економічній свідомості підлітків.

Виклад основного матеріалу. Одним із вирішальних чинників розвитку економічної культури школяра ми обгрунтовуємо [1] його ставлення до особистої власності. Воно формується в результаті інтеріоризації дитиною того значення, якого надає соціальне оточення особистому майну (матеріальному і духовному) і взаєминам, які виникають в цьому оточенні з приводу привласнення обмежених благ і перетворення їх на «свої особисті». У ставленні дитини до особистої власності відображається суб'єктивована модель реальності тих відносин дитини, у які вона включена з приводу привласнення блага. Отже, припускаємо, що вивчити особливості такої моделі означало б виявити суб'єктивні способи оцінювання відображеної економічної реальності, на яких, як наслідок, засновується вибір способів вчиняти у просторі відносин з іншими суб'єктами привласнення.

Контент-аналіз метафоричного матеріалу, 3 якого конструюється учнем суб'єктивована реальність особистої власності, став для нас тим методичним інструментом, який би дозволив емпірично вивчити особливості ставлення до особистої власності школярів. Метафоричні моделі особистої власності підлітків вивчались як загальне тематичне поле однорідних понять, яке застосовували учні для характеристики відносин особистої власності. Емпіричні матеріали були отримані у ході опитування 80 учнів 7-8-х класів (віком 13-14 років), проведеного в 2013-2014 рр. у ЗОШ №329 та №274 м. Києва. Учням було запропоновано пофантазувати і написати невеличку казку про особисті речі, майно, гроші людини, яка має своє господарство.

За результатами опитування проводився контент-аналіз усіх згадувань-метафор щодо власності, які потім групувались відповідно до використовуваних метафоричних моделей. Підраховувалась частота слів та словосполучень за кожною моделлю і робився висновок щодо особливостей економічного мислення і репрезентацій власності у свідомості підлітків.

У казках підлітків було зафіксоване використання наступних 17 метафоричних моделей особистої власності (частота використання подана у \% до загального числа згадувань - 479 використань) (табл. 1):

1. Монетаризація - модель, що характеризується переважно описом особистого майна казкового героя чи описом самого героя у більшості казок в термінах грошових одиниць. Той факт, що монетаризація економічного змісту казок становить найбільшу частку серед інших метафоричних 
моделей, підтверджує припущення багатьох економічних психологів [2; 4; 8$]$ щодо провідної ролі кишенькових грошей у економічній соціалізації підлітків.

Таблиияя 1

Частота використання метафоричних моделей в казках підлітками, у \% до загальної кількості використання

\begin{tabular}{|cl|c|}
\hline \multicolumn{2}{|c|}{ Метафорична модель } & Частота використання \\
\hline 1. & Монетаризація & 24 \\
\hline 2. & Темпоральність & 17 \\
\hline 3. & Дії & 14 \\
\hline 4. & Рух & 11 \\
\hline 5. & Вмістилище & 8,4 \\
\hline 6. & Містика & 5,5 \\
\hline 7. & Розмірність, порахованість благ & 3,6 \\
\hline 8. & Персоніфікація & 3,5 \\
\hline 9. & Війна, боротьба & 2,9 \\
\hline 10. & Живі істоти & 2 \\
\hline 11. & Фінансові прагнення & 1,8 \\
\hline 12. & Сім'я & 1,5 \\
\hline 13. & Адміністративні одиниці & 1,2 \\
\hline 14. & Таємничість & 1 \\
\hline 15. & Прагматизм & 1 \\
\hline 16. & Благодійність & 1 \\
\hline 17. & Природні стихії & 0,6 \\
\hline
\end{tabular}

2. Темпоральність - це характеристика казкових подій, пов'язаних з особистою економікою, у термінах часу: ретроспективні характеристики (з далеких часів, у дитинстві, бувало, жила-була дівчинкасирітка) становлять $8 \%$, характеристики теперішнього часу ( $\epsilon$, маю, дають гроші) - 6,2\%, проспективні характеристики (буде рости, дасть, роздам, допоможу, піклуватимусь) - менше $1 \%$ загальної кількості згадувань про час. Бачимо, що підлітки спираються на економічний досвід, який уже мають, аналізують економічні події, які мали місце чи тривають тепер. Підлітки не схильні прогнозувати їх, отже поки що не спираються на інтуїцію, власну креативність та ініціативу. Окрім того, особиста власність у підлітковому віці пов'язана 3 нерегулярністю надходжень, отже - із залежністю особистої економіки підлітка від зовнішньої допомоги.

3. Дії - це характеристика складових особистої економіки героя як таких, що передбачають здійснення завершеного акту діяльності, тож їі наявність у казках підлітків означає, що їх особиста економіка характеризується спрямованістю на досяг- нення усвідомлюваної мети, довільність і навмисність економічної активності. Метафорична модель дії стосується у підлітків переважно активних дій героїв казки (узяв, накупив, накопичив), пов'язаних зі свідомим докладанням зусиль для досягнення певної економічної мети. Переважання метафори способів надходження особистих благ (7\%) порівняно зі способами їх відчуження свідчить про категоризацію себе як суб' єкта привласнення та примноження економічних благ. При цьому слід відзначити суперечливість цього процесу у підлітків, оскільки серед способів як найбільш реальні й адекватні поряд з економією (3,3\%) і заробітком своєю працею $(1,5 \%)$ осмислюється містична поява благ «нізвідкіля» $(1,6 \%)$. Метафорична модель дії у підлітків включає в себе і метафори витрат (4\%).

4. Рух - характеристика змін в системі відносин привласнення-відчуження. Багаторазове $(11 \%)$ застосування підлітками метафоричної моделі руху акцентує і підкреслює осмислення ними ролі учасників відносин власності як активної, перетворюючої та пов'язаної з контролем і зміна- 
ми. Так, серед прикладів метафори руху підлітки згадують захист (особливо яскраво це видно у зв'язку з метафоричними моделями боротьби, війни), накопичення й обмін (купівля-продаж).

5. Вмістилище - це осмислення особистих благ як таких, що поміщені в ємність, призначену для їх збереження та накопичення. Серед зразків метафоричної моделі вмістилища у підлітків переважають такі, що пов'язані з побутовими речами (скарбничка, чарівний горщзик, чарівний гаманець, моя/чужа кишеня). Вони відповідають звичним кліше, мовним штампам, використовуваним у побутовому спілкуванні. Отже, ними задаються формальні, передбачувані, а значить контрольовані й зрозумілі для підлітків складові відносин особистої власності. Останні, очевидно, у підлітків пов'язані з накопиченням та збереженням, економією благ. При цьому слід констатувати і наявність таких складових даної метафоричної моделі, як природні (печера) та штучні (споруди, будівлі: nidземелля, школа, стара хатинка, схованка, ворота, палаи) вмістилища. Використання метафоричної моделі споруди - символу нерухомої штучної структури порівняно великих розмірів - у описах казкових подій, на нашу думку, надає статичності, масштабності ідеї вмістилища. Згадування підлітками таких більш масштабних вмістилищ ми схильні розглядати як спроби виходу за межі безпосередньо сприйманого й осяжного світу особистої економіки, розсування іiі меж, виходу поза межі буденних взаємин накопичення і збереження, спроби пізнання більш широких відносин власності. Або, навпаки, - до бажання уникнути конкретизації у відносинах особистої власності.

6. Наявність метафори містичного в текстах підлітків підтверджує відсутність в уявленнях про особисту економіку чіткості і визначеності, свідчить про неоднозначність, прихованість, непроявленість окремих економічних явищ. Оскільки ця метафорична модель стосувалась переважно головних героїв та джерел надходження i зберігання особистих благ, то слід конс- татувати, що актуальними в підлітковому віці $є$ проблеми економічного самовизначення та пов'язаний 3 цим вибір способів матеріального самозабезпечення, які розв'язуються зазвичай на наступному віковому етапі.

7. Розмірність, порахованість благ - застосовування певної кількості незалежних числових параметрів, необхідних для опису стану об'єктів у казці. Такими об'єктами в казках підлітків були блага. Застосовувались переважно вартісні характеристики щодо благ (останні гроші, 1, 2 долари, євро, 200 грн, 500 грн, 2 грн). Оскільки найбільш згадуваними були купюри невисокої вартості (1-2 долари та від 1 до 50 грн), можемо судити про переважно невисокі монетарні домагання опитаних підлітків.

8. Персоніфікація - приписування економічним явищам, подіям рис та властивостей, притаманних людині, олюднення, оживлення їх (балакучі гроші; самотня гривня, жив самотній долар; тепер витрачені гроші живуть у чужій кишені; гроші роблять все; жсили-були гроші). Використання цієї метафоричної моделі підтверджує думку про те, що особиста річ осмислюється підлітками як символ, частина способу життя, втілення бажань. Речі не залишаються безликими, «чиїмись». Вони психологічно привласнюються, стаючи «своїми».

9. Війна, боротьба - осмислення казкових подій як військових, як протиборства і конфліктної взаємодії, в якій конкуруючі групи мають досить рівні сили, щоб зробити результат бою невизначеним. Припускаємо, що підлітки демонструють готовність як до захисту своїх інтересів і благ (облога, захист, оборона, охорона), так i до активного їх відстоювання та до перемоги в конкурентній боротьбі (зброя, війна, битва, повстання, перемога). Про те й інше свідчить використання метафори війни для означення подій в економічній казці.

3 таблиці 1 видно, що інші вісім метафоричних моделей, виділених із казок підлітків (природних стихій, прагматизму, 
сім’і, війни, споруд, живих істот, адміністративних одиниць), $є$ мало навантаженими (частота використання кожної $з$ них становить не більше $2 \%$ ). Для нас це означає, що особиста власність на підлітковому етапі вже концептуалізується з більш дорослої, раціональної точки зору. Так, рухливість економічних процесів, їх мінливість слід розглядати з раціональної точки зору, як притаманні не тільки живим істотам, а й усім динамічним явищам. Зменшення ваги метафоричної моделі сімейності свідчить про зниження значущості зв'язків особистої економіки підлітка 3 життям його сім'ї, про зниження міри іiі інкорпорованості у сімейну економіку, отже, про зростання економічної самостійності. Зниження частоти втаємничування підлітками джерел, 3 яких надходять матеріальні блага (1\%), свідчить про розуміння опитаними універсальності способів самозабезпечення. Викликає занепокоєння низький рівень зваженості, прагматизму i душевності у відносинах особистої власності підлітків як свідчення відсутності орієнтацій на норми добра і добросердя (йдеться про моделі прагматизму і благодійності). Низька частота використання моделі природних стихій підкреслює осмислення підлітками особистої власності як більш-менш контрольованого явища, поза фаталізмом і випадковістю, які трапляються в природі.

Висновки. Таким чином, підсумовуючи, зазначимо, що в ході дослідження нами підтверджена провідна роль кишенькових грошей в економічній соціалізації підлітків, показана нерегулярність надходжень, усвідомлення ними об'єктивної залежності особистої економіки від зовнішньої підтримки і допомоги. При цьому з'ясоване прагнення підлітків до економічної самостійності, до контрольованості надхо- джень особистих благ, до незалежності від сімейної економіки та від впливу випадку і фатуму. Показано, що підлітки спираються на отриманий економічний досвід, не схильні поки що прогнозувати економічні події, спиратись на власну інтуїцію, креативність та ініціативу.

Показане осмислення підлітками ролі власника як активної, перетворюючої та пов'язаної з контролем і змінами; спроби виходу поза межі буденних взаємин накопичення i збереження; констатація ними неоднозначності, прихованості, непроявленості окремих економічних явищ; акцентування уваги на освоєності, приналежності економічних благ; демонстрація готовності як до захисту своїх інтересів та благ, так і до активного їх відстоювання й до перемоги в конкурентній боротьбі. Виявлено, що особиста власність на підлітковому етапі вже концептуалізується 3 більш-менш дорослої, раціональної точки зору. Так, економічні процеси осмислюються підлітками як рухливі, мінливі. Збільшується прагнення підлітка бути менш залежним та інкорпорованим у сімейну економіку, отже зростає прагнення до економічної самостійності. Способи матеріального самозабезпечення осмислюються як універсальні. При цьому для підлітків характерний низький рівень зваженості, прагматизму й орієнтацій на норми добра і добросердя у відносинах особистої власності.

В контексті вищесказаного перспективним для прояснення соціально-психологічних закономірностей становлення економічної культури підлітків, як ми вважаємо, $€$ вивчення інших внутрісистемних (афективних і поведінкових) складових цього явища.

\section{Список використаних джерел:}

1. Дембицька Н. М. Становлення основ економічної культури школяра у просторі шкільної освіти / Н. М. Дембицька // Духовність у становленні та розвитку особистості : матеріали VIII Міжнародної науково-практичної конференції «Духовність у становленні та розвитку особистості», 9-11 жовтня 2014 р., м. Івано-Франківськ. - Івано-Франківськ : Видво ДВНЗ «Прикарпатський національний університет імені Василя Стефаника», 2014. - С. 154-166. 
2. Економічна соціалізація молоді: соціально-психологічний аспект : наукове видання / І. В. Білоконь, Н. М. Дембицька, І. К. Зубіашвілі та ін. // [заг. ред. В. В. Москаленко]. К. : Український центр політичного менеджменту, 2008. - 336 с.

3. Журавлев А. Л. Экономическое самоопределение: Теория и эмпирические исследования / А. Л. Журавлев, А. Б. Купрейченко. - М. : Институт психологии РАН, 2007. - 480 с.

4. Зубіашвілі І.К. Монетарна культура як фактор стабільності суспільства / І. К. Зубіашвілі // Актуальні проблеми психології : зб. наук. праць Інституту психології імені Г. С. Костюка НАПН України / за ред. академіка С.Д. Максименка. - К., 2014. - Т. 11. - Вип. 9. - С. 396-407.

5. Идея системности в современной психологии / Под ред. В.А. Барабанщикова. - М. : Изд-во Института психологии РАН, 2005. — 496 с.

6. Лавренко О.В. Концептуальні засади дослідження ролі морального фактора в економічній культурі особистості / О.В. Лавренко // Актуальні проблеми психології : зб. наук. праць Інституту психології імені Г.С. Костюка НАПН України. - Том 11. - Вип. 9. — К. : Фенікс, 2014. - С. 470-483.

7. Лакофф Дж. Метафоры, которыми мы живем / Дж. Лакофф, М. Джонсон // Теория метафоры. - М. : Прогресс, 1990. - С. 387-415.

8. Москаленко В.В. Соціалізація особистості : монографія / В. В. Москаленко. — К. : Фенікс, 2013. - С. 339-390.

9. Общение и познание / Под ред. В. А. Барабанщикова и Е. С. Самойленко. - М. : Изд-во Института психологии РАН, 2007. - 495 с.

Аннотация. Статья посвящена актуальной проблеме концептуализации реальности отнотений личной собственности учениками подросткового возраста. Показаны результаты контент-анализа метафорического содержания экономических сказок подростков. Соответственно описываются особенности понимания и оиенки подростками реальности отнотений личной собственности. В частности анализируются метафорические модели личных благ человека, который ведет свое хозяйство. Эти модели показаны как характеристики когнитивных, а не лингвистических средств, с помощьью которых действительность личной собственности подростками осмысливается, категорируется и конщептуализируется. Показаны особенности осмысления подростками роли собственника в личной экономике.

Ключевые слова: подростки, экономическое сознание, экономическая культура личности, личная собственность, метафорическая модель.

Abstracts. Article concerns very actual problem of the conceptualization of reality of teenagers' personal property relations. The article analyzes metaphorical content of teenagers' economic stories. It is shown that teenagers use pervious economic experience. They are do not tend to predict economic events and are don't based on intuition, creativity and own initiative.

This article shows the teenagers' understanding themselves as active owners, who is associated wit control and changes. Teenagers demonstrate an attempts to move beyond the perceived direct and foreseeable world of the personal economy; show an attempts to feel property in level of emotions, focusing on its cultivation and accessories.

They demonstrate the willingness to defend their interests and benefits, to win the competition. Teenagers are characterized by understanding of the personal property as a mobile processes of growth, development, change, metamorphosis.

The personal property on the teenage stage are conceptualized with more or less rational point of view. Thus, teenagers' economic processes are conceptualized as movable, changing. Increasing of teenager's desire to be less dependent and incorporated in the family economy, therefore, increases the desire for economic independence. Methods of financial self-sufficiency are interpreted as universal by teenagers. This is typical for teenagers poor pragmatism and orientations of the norms of goodness and kindness in relation to personal property.

Keywords: teenagers, metaphorical model, economic consciousness, personal property, economic culture of personality. 